\title{
Mechanosensitive miRNAs and Bone Formation
}

\author{
Zhihao Chen ${ }^{1,2,3}$, Yan Zhang ${ }^{1,2,3}$, Chao Liang ${ }^{2,4}$, Lei Chen ${ }^{1,2,3}$, Ge Zhang ${ }^{2,4, *}$ \\ and Airong Qian 1,2,3,* (iD \\ 1 Laboratory for Bone Metabolism, Key Laboratory for Space Bioscience and Biotechnology, School of Life \\ Sciences, Northwestern Polytechnical University, Xi'an 710072, China; chzhh@mail.nwpu.edu.cn (Z.C.); \\ zhangyan0911@mail.nwpu.edu.cn (Y.Z.); chenlei1994@mail.nwpu.edu.cn (L.C.) \\ 2 NPU-HKBU Joint Research Centre for Translational Medicine on Musculoskeletal Health in Space, \\ Northwestern Polytechnical University, Xi'an 710072, China; liangchao512@163.com \\ 3 Shenzhen Research Institute of Northwestern Polytechnical University, Shenzhen 518057, China \\ 4 Institute for Advancing Translational Medicine in Bone and Joint Diseases, School of Chinese Medicine, \\ Hong Kong Baptist University, Hong Kong 999077, China \\ * Correspondence: zhangge@hkbu.edu.hk (G.Z.); qianair@nwpu.edu.cn (A.Q.); \\ Tel./Fax: +852-3411-2958 (G.Z.); +86-29-8849-1840 (A.Q.)
}

Received: 8 June 2017; Accepted: 28 July 2017; Published: 2 August 2017

\begin{abstract}
Mechanical stimuli are required for the maintenance of skeletal integrity and bone mass. An increasing amount of evidence indicates that multiple regulators (e.g., hormone, cytoskeleton proteins and signaling pathways) are involved in the mechanical stimuli modulating the activities of osteogenic cells and the process of bone formation. Significantly, recent studies have showed that several microRNAs (miRNAs) were sensitive to various mechanical stimuli and played a crucial role in osteogenic differentiation and bone formation. However, the functional roles and further mechanisms of mechanosensitive miRNAs in bone formation are not yet completely understood. This review highlights the roles of mechanosensitive miRNAs in osteogenic differentiation and bone formation and underlines their potential therapeutic application for bone loss induced by the altering of mechanical stimuli.
\end{abstract}

Keywords: mechanical stimuli; mechanosensitive miRNAs; bone formation; osteogenic differentiation

\section{Introduction}

Bone, as a specifically mechanical sensory organ, is constantly remodeled (bone formation and bone resorption) under a normal mechanical environment [1,2]. Post-natal bone formation is controlled by osteogenic cells, which are believed to be responsive to different mechanical stimuli [3,4]. Clinically, a lack of mechanical stimuli (e.g., aging, paralysis) or exposure to external mechanical unloading (e.g., during bed-rest or hind-limb unloading, or under the conditions experienced by astronauts) reduce weight-bearing bone formation and weaken bone structure [5-8]. Previous reports from our laboratory and others have demonstrated that multifactorial regulators are involved in the mechanical stimuli modulating the activity of osteogenic cells and bone formation, such as hormones or cytokine (e.g., parathyroid hormone [9], glucocorticoid [10], follistatin-like 3 [11]), cytoskeleton proteins (e.g., microtubule actin crosslinking factor 1 [12], connexin 43 [13]), signaling pathways (e.g., Wnt signaling $[14,15])$ and microRNAs (miRNAs).

miRNAs, a newly discovered class of evolutionarily conserved short noncoding RNAs, play a vital role in diverse physiological and pathological processes, including cell differentiation, proliferation, apoptosis and cancer development [16-18]. Emerging evidence has showed that miRNAs are involved in bone formation [19-21]. Significantly, recent studies have discovered that miR-503-5p [22] and miR-103a [23] are sensitive to different mechanical stimuli when regulating osteogenic cell differentiation and bone formation. Here, miRNA, which expression alters with mechanical use or disuse, was regarded 
as "mechanosensitive microRNA". However, the cellular and molecular mechanisms underlying how mechanosensitive miRNAs impacted on bone formation have not yet been completely understood. This review aims to provide an overview of the relationship between mechanosensitive miRNAs and bone formation, including mechanosensitive miRNAs and osteogenic differentiation; mechanosensitive miRNAs and osteoblast proliferation; and mechanosensitive miRNAs and bone formation.

\section{Biogenesis and Function of miRNAs}

miRNAs are evolutionary conserved short ( 22 nucleotides) non-coding single-stranded RNAs, that emerged as post-transcriptional regulators of gene expression either by repressing target messenger RNAs (mRNAs) translation efficiency or resulting in target mRNAs degradation [17,24,25]. Mature miRNAs are produced through a series of biological processes which are initiated with transcription [26]. The primary transcript (pri-miRNA), hundreds of nucleotides long, has a local hairpin structure embedding mature miRNA sequences, and pri-miRNA is transcribed from the intragenic or intergenic DNA regions carried out by RNA polymerase II. Following transcription, pri-miRNA is cleaved by Drosha or DGCR8 (Di George syndrome critical gene 8) into precursor miRNA (pre-miRNA) with a 70 nucleotide stem-loop structure. Then, pre-miRNA is exported from the nucleus to the cytoplasm by the exportin- 5 complex and processed to form mature miRNA by Dicer in the cytoplasm. Finally, mature miRNA is assembled into an RNA-induced silencing complex (RISC) with Ago 2 (Argonaute 2), which guides RISC directly to the UTR (untranslated regions) of its target mRNA [26,27].

It has been reported that multiple miRNAs have been postulated to play a vital role in diverse biological processes, including bone formation [21,27]. The importance of miRNAs in bone formation has been addressed by the osteoblast-type-specific deletion of Dicer, required for miRNA biogenesis, generating with a perinatal phenotype of delayed-bone mineralization and a subsequent increase in postnatal bone formation [28]. Additionally, Dicer deficiency in osteoclasts not only reduced the number of osteoclasts and the osteoclast surface, but also suppressed the mineral apposition rate (MAR) and bone formation rate (BFR) in vivo [29]. There is an increasing amount of evidence that miRNAs are also involved in the cellular response to various mechanical stimuli in diverse organs and cells [30-35]. Significantly, recent studies have discovered that some mechanosensitive miRNAs played important roles in the differentiation or proliferation of osteogenic cells in vitro and bone formation in vivo [22,23,36-40].

\section{Mechanosensitive miRNAs and Osteogenic Differentiation}

Mechanosensitive miRNAs are identified to be involved in osteogenic differentiation due to the expressions of these miRNAs changing with mechanical stimuli, altering osteogenic differentiation. Microarray and bioinformatics analysis are effective and prompt methods to search for mechanosensitive miRNAs altering with different mechanical stimuli in osteogenic cells (Table 1). Two microarray data of MC3T3-E1 cells subjected to a four-point bending stretch suggested that miR-3077-5p, -3090-5p, -3103-5p, -191*, and -3070a were significantly up-regulated, in contrast, miR-466i-3p, -466h-3p, -218 and -33 were down-regulated; accompanied by alkaline phosphatase (ALP) activity, mRNA levels of Alp, Ocn (osteocalcin), Col I (Collage I), and the protein levels of BMP-2 and BMP-4 increased in the mechanical stretch group [41,42]. Furthermore, analysis of putative target genes indicated that this mechanosensitive miRNAs might be involved in osteoblast differentiation [41,42]. Additionally, four-point bending stretch could have significantly promoted cementoblastogenesis, mineralized nodule formation, and miR-146b-5p expression in OCCM-30 cells. Smad4 (SMAD family member 4), a common mediator of both BMP (Bone morphogenetic protein) and TGF- $\beta$ (Transforming growth factor- $\beta$ ) signaling, was a target gene of mechanosensitive miR-146b-5p; this was confirmed by a dual-luciferase reporter assay [43].

According to Wolff's law, mechanical forces are divided into stretch stress, hydrostatic compressive force, and shear stress due to fluid flow in vitro [44]. Four-point bending and Flexcell were both used to supply stretch stress in osteogenic cells. The Flexcell stretch system was a common device for studying the effects of mechanical stretch on periodontal ligament stem cells (PDLSCs) and periodontal ligament 
cells (PDLCs), which were capable of osteogenic differentiation under mechanical stimuli $[39,45]$. In genome-wide miRNA expression profiling of PDLSCs, the expressions of miR-1246, -5096, -638, -663, $-21,-4492$, and -4734 increased, while miR-3195, -4281 , and -3178 decreased under Flexcell stretch [46]. Another microarray indicated that the expressions of miR-195-5p, -424-5p, -1297, -3607-5p, -145-5p, -4328 , and -224-5p were significantly lower in PDLCs subjected to Flexcell stretch for $72 \mathrm{~h}$ [47]. Fluid shear stress (FSS), another common and potent type of mechanical stimulus in bone cells, enhanced osteogenic gene expression, ALP activity, and mineralization, accompanied with a decrease of miR-20a, $-21,-19 b,-34 a,-34 c,-140$, and -200b in MC3T3-E1 cells [48]. The above-mentioned mechanosensitive miRNAs were putatively involved in osteogenic differentiation (Table 1). In our study, a biaxial random positioning machine (RPM) was used to investigate the mechanical unloading effects on osteoblasts [49] and osteocytes [50]. In RPM microarray data [50], we found that miR-15a (fold change $=0.426$ ), miR-221 (fold change $=0.665$ ) and miR-29a (fold change $=0.513$ ) were down-regulated in MLO-Y4 osteocytes under an RPM unloading condition [50].

Table 1. Mechanosensitive miRNAs screened by microarray are putatively involved in osteogenic differentiation.

\begin{tabular}{|c|c|c|c|c|}
\hline miRNAs & $\begin{array}{l}\text { Mechanical Stimuli and } \\
\text { Parameters }\end{array}$ & Microarray Groups & Samples & Reference \\
\hline miR-218, -33, 191*, 3070a & $\begin{array}{c}\text { Stretch stress } \\
\text { (Four-point bending) } \\
2500 \mu \varepsilon, 0.5 \mathrm{~Hz}\end{array}$ & 0 and $8 \mathrm{~h}$ & MC3T3-E1 & [41] \\
\hline $\begin{array}{c}\operatorname{miR}-3077-5 p,-3090-5 p,-3103-5 p \\
-466 h(i)-3 p\end{array}$ & $\begin{array}{c}\text { Stretch stress } \\
\text { (Four-point bending) } \\
2500 \mu \varepsilon, 0.5 \mathrm{~Hz}\end{array}$ & 0 and over $3 \mathrm{~d}(1 \mathrm{~h} / \mathrm{d})$ & MC3T3-E1 & [42] \\
\hline miR-146b-5p & $\begin{array}{c}\text { Stretch stress } \\
\text { (Four-point bending) } \\
2000 \mu \varepsilon, 0.5 \mathrm{~Hz}\end{array}$ & 0 and $18 \mathrm{~h}$ & OCCM-30 & [43] \\
\hline $\begin{array}{l}\mathrm{miR}-1246,-5096,-638,-663,-21, \\
-4492,-4734,-3195,-4281,-3178\end{array}$ & $\begin{array}{c}\text { Stretch stress } \\
\quad \text { (Flexcell) } \\
10 \% \text { strain, } 1.0 \mathrm{~Hz}\end{array}$ & 0 and $12 \mathrm{~h}$ & PDLSCs & [46] \\
\hline $\begin{array}{c}\operatorname{miR}-195-5 p,-424-5 p,-1297 \\
-3607-5 p,-145-5 p,-4328,224-5 p\end{array}$ & $\begin{array}{c}\text { Stretch stress } \\
\text { (Flexcell) }\end{array}$ & 0 and $72 \mathrm{~h}$ & PDLCs & [47] \\
\hline $\begin{array}{c}\text { miR-20a, }-21,199 b,-34 a(c), \\
-140,-200 b\end{array}$ & $\begin{array}{c}\text { FSS } \\
12 \mathrm{dyn} / \mathrm{cm}^{2}\end{array}$ & $0,0.5$ and $1 \mathrm{~h}$ & MC3T3-E1 & [48] \\
\hline
\end{tabular}

d: day; FSS: Fluid shear stress; h: hour; miR: microRNA; OCCM: immortalized osteocalcin positive cementoblasts; PDLCs: periodontal ligament cells; PDLSCs: Periodontal ligament stem cells.

\subsection{Mechanosensitive miRNAs Promoted Osteogenic Differentiation}

Several mechanosensitive miRNAs were reported to promote osteogenic differentiation (Table 2) $[39,40]$. To deeply explore the function of mechanosensitive miR-21 on the osteogenic differentiation of stretch-induced PDLSCs, Wei's group tested the correlation analysis between stretch times and miR-21 [46,51]. The expression of miR-21 and osteogenic marker genes (Runx2 (runt related transcription factor 2) and $O c n$ ) gradually rose with stretch times increasing by degrees. Further, miR-21's target gene Acvr $2 b$ (activin receptor type IIB) partially inhibited the stretch-induced ALP activity and Run $x 2$ and Ocn gene expression, revealing that mechanosensitive miR-21 facilitated stretch-induced PDLSC osteogenic differentiation through suppressing Acvr2b. The miR-21 level was down-regulated approximately 70\% under FSS in MC3T3-E1 cells [48]. Additionally, miR-21 was reported to promote the level of osteogenic differentiation and increase matrix mineralization by directly repressing Smad7 in MC3T3-E1 cells [52], while miR-21 expression gradually decreased during PDLC mineralization [53]. The results of these studies indicated that miR-21 might have a diametric role in different types of bone cell osteogenic differentiation and under various mechanical stimuli. This phenomenon also appeared in another miRNA (miR-33), which was reported to decrease in the mechanical stretch group in MC3T3-E1 
cells [41]. However, one subtype of miR-33, miR-33-5p expression, was significantly up-regulated under increasing FSS, and the knockdown of miR-33-5p partially prevented FSS-induced osteoblast differentiation [40]. Not only was miR-33-5p sensitive to mechanical loading, but it was also responsive to mechanical unloading in MC3T3-E1 cells. In view of miR-33-5p positively regulating osteoblast differentiation, Wang investigated the roles of miR-33-5p in osteoblast activity under mechanical unloading. The overexpression of miR-33-5p partially attenuated the inhibition of MC3T3-E1 osteogenic differentiation induced by mechanical unloading and Hmga2 (high mobility group AT-hook 2), as miR-33-5p's target, was confirmed to negatively regulate osteoblast differentiation [40].

FSS was also used to study the effects of mechanical stimuli on PDLCs. It is reported that increasing FSS in fixed increments regulated not only the PDLC proliferation and differentiation, but also miR-132 expression. Further, phosphorylated levels of the PI3K (phosphatidylinositol-3 kinase), AKT (serine/threonine kinase), mTOR (mammalian target of rapamycin), and p70S6K (ribosomal protein S6 kinase) proteins were significantly greater with FSS-treatment, however they were nonetheless blocked by the miR-132 inhibitor. The subsequent results suggested that up-regulation of miR-132 induced by FSS could activate the mTOR signaling pathway and PDLC osteogenic differentiation [39]. Bio-stretch was another type of stretch stress device, which exerted a uniaxial stretch with square wave patterns and was used to simulate stretch in chondrocytes. miR-365 was identified as the first mechanosensitive miRNA to stimulate chondrocyte differentiation via directly targeting Hadc4 (hystone deacetylase 4) [38].

Table 2. Mechanosensitive miRNAs promote osteogenic differentiation.

\begin{tabular}{cccccc}
\hline miRNAs & Mechanical Stimuli & Methods & Target Gene & Samples & Reference \\
\hline miR-21 & $\begin{array}{c}\text { Stretch stress } \\
\text { (Flexcell) }\end{array}$ & $\begin{array}{c}10 \% \text { strain } 1.0 \mathrm{~Hz} \\
6,12,24, \text { or } 48 \mathrm{~h}\end{array}$ & Acvr2b & PDLSCs & {$[51]$} \\
\hline miR-365 & $\begin{array}{c}\text { Stretch stress } \\
\text { (Bio-stretch) }\end{array}$ & $\begin{array}{c}8 \% \text { deformation, } 1 \mathrm{~Hz} \\
15 \mathrm{~min} / \mathrm{h}, 24 \mathrm{~h}\end{array}$ & Hdac4 & chondrocyte & {$[38]$} \\
\hline miR-132 & FSS & $\begin{array}{c}3,6,9,12,15 \mathrm{dyn} / \mathrm{cm}^{2}, \\
6 \mathrm{~h}\end{array}$ & - & PDLCs & [39] \\
\hline miR-33-5p & $\begin{array}{c}\text { FSS } \\
\text { Unloading }\end{array}$ & $\begin{array}{c}10 \mathrm{dyn} / \mathrm{cm}^{2}, 1 \mathrm{~h} \\
24 \mathrm{rpm}, 48 \mathrm{~h}\end{array}$ & Hmga2 & MC3T3-E1 & {$[40]$} \\
\hline
\end{tabular}

Acvr2b: activin receptor type IIB; FSS: Fluid shear stress; Hmga2: high mobility group AT-hook 2; Hdac4: hystone deacetylase 4; PDLCs: periodontal ligament cells; PDLSCs: Periodontal ligament stem cells.

\subsection{Mechanosensitive miRNAs Inhibited Osteogenic Differentiation}

Despite several mechanosensitive miRNAs promoting osteogenic differentiation (Table 2), there are more mechanosensitive miRNAs reported to serve as inhibitors in osteogenic differentiation (Table 3). Li et al. have demonstrated miR-154-5p was remarkably down-regulated in adipose-derived mesenchymal stem cells (ADSCs) subjected to four-point bending stretch. ALP activity and matrix mineralization were altered treatments with lentivirus-miR-154-5p or inhibitor of miR-154-5p under mechanical stretch, which indicated that mechanical-stretch-sensitive miR-154-5p prevented osteogenic differentiation of ADSCs through the Wnt/PCP (planar-cell-polarity) pathway by directly targeting Wnt11 (Wnt family member 11) [37]. Another miR-195-5p also targeted a Wnt family member (WNT $3 A)$ to inhibit PDLC differentiation under Flexcell stretch. In addition, miR-195-5 $p$ was involved in FGF (fibroblast growth factor) and BMP signaling through targeting FGF2 and BMPR1A (bone morphogenetic protein receptor-1A) during osteogenic differentiation of PDLCs [54]. Although compression force was a type of mechanical loading condition, the effects of compressive force on osteogenic differentiation were opposite to other loading methods [55]. It is reported that the miR-29 family, including miR-29a, miR-29b and miR-29c, significantly decreased approximately 0.5 -fold and suppressed the target extracellular matrix gene (Col1a1, Col3a1 and Col5a1) expression in PDLCs treated 
with Flexcell stretch. On the contrary, the significantly increased (1.8-4-folds) expression of the miR-29 family were detected when PDLCs were subjected to compressive force [55].

In addition to regulating PDLSCs and PDLCs osteogenic differentiation, Flexcell-strain-sensitive miRNA contributed to osteoblast and Bone marrow mesenchymal stem cells (BMSC) osteogenic differentiation [22,23]. Zuo et al. identified that a mechanosensitive miRNA, miR-103a, reduced osteoblast activity and matrix mineralization through binding to Run $x 23^{\prime}$ UTR in hFOB 1.19 cells under Flexcell stretch [23]. Recently, miR-503-5p was observed to be a negative regulator of stretch-mediated osteogenic differentiation in BMSCs [22].

Extracorporeal shockwave (ESW), another type of mechanical stress, transduced the mechanical signals into biological signals and promoted osteogenic differentiation [56]. The miR-138 level was decreased with post-ESW treatment and the overexpression of miR-138 abrogated osteogenic differentiation induced by ESW through down-regulating FAK (Focal adhesion kinase), Runx2 expression and mineralization in MSCs (mesenchymal stem cells) [57]. In BMSCs, miR-138 was reported to inhibit osteogenic differentiation by targeting FAK, and antagomir-138 (miR-138 inhibitor) obviously enhanced ectopic bone formation $[58,59]$.

Table 3. Mechanosensitive miRNAs inhibit osteogenic differentiation.

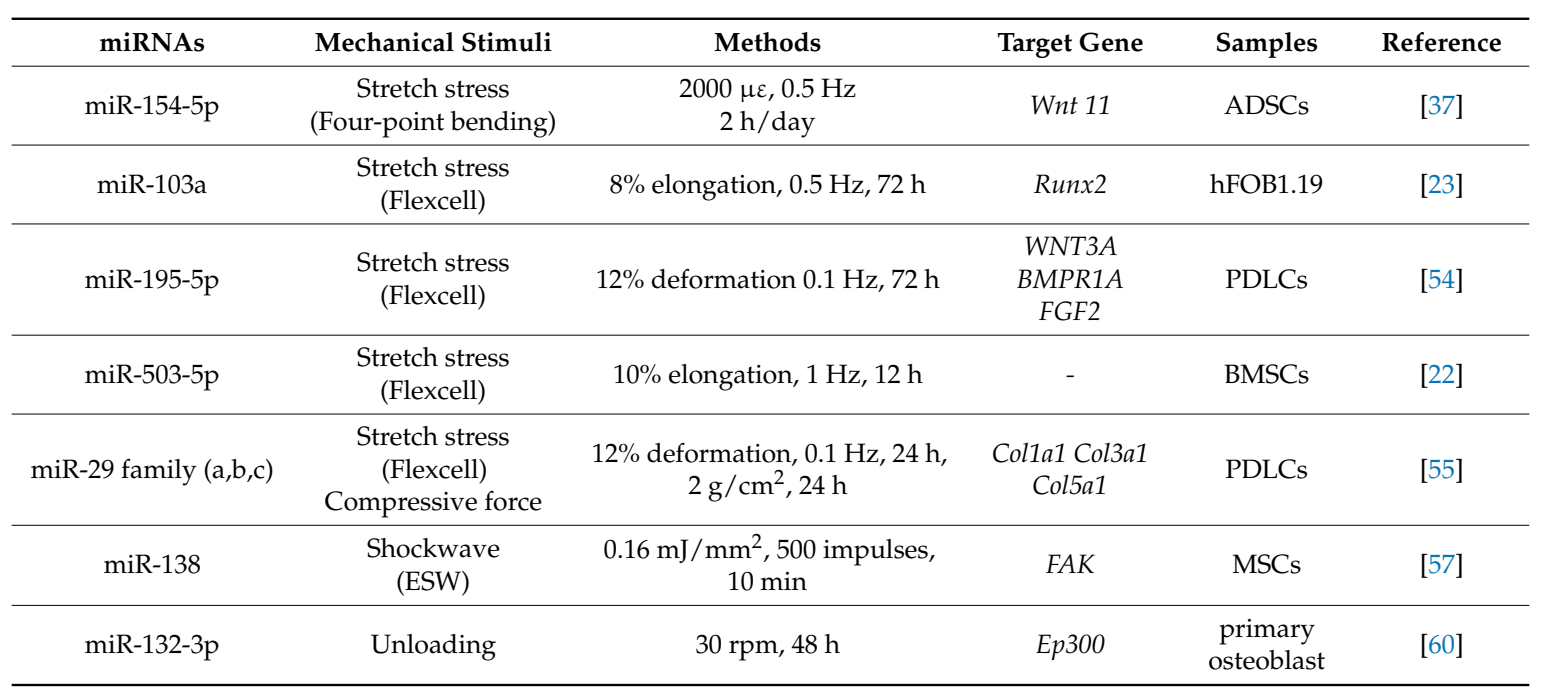

ADSCs: adipose-derived mesenchymal stem cells; BMPR1A: bone morphogenetic protein receptor-1A; BMSCs: Bone marrow mesenchymal stem cells; Col I: Collage I; Ep300: E1A binding protein p300; ESW: Extracorporeal shockwave; FAK: Focal adhesion kinase; FGF2: fibroblast growth factor 2; FSS: Fluid shear stress; Hmga2: high mobility group AT-hook 2; miR: microRNA; MSCs: mesenchymal stem cells; PDLCs: periodontal ligament cells; Runx2: runt related transcription factor 2; WNT3A: WNT family member 3A. WNT11: WNT family member 11.

In a preceding study, miR-132 positively regulated FSS-induced PDLC osteogenic differentiation through the mTOR signaling pathway [39]. However, miR-132-3p, one subtype of miR-132, was up-regulated (about 2.5-fold) in a mechanical unloading group and negatively correlated with osteoblast differentiation in primary rat osteoblasts. Moreover, Ep300 (E1A binding protein p300), miR-132-3p's target, significantly decreased under mechanical unloading and suppressed the activity and acetylation of Runx2, a key regulatory factor of osteoblast differentiation [60]. This is further evidence that the same miRNA played opposite roles in the differentiation of different osteogenic cells subjected to various mechanical stimuli. Mechanosensitive miRNAs temporally changed with mechanical use/disuse, and played important roles in osteogenic differentiation under different mechanical conditions. Without mechanical stimuli, the gain or loss of function of the mechanosensitive microRNAs still affects many bio-active molecules indispensable to the regulation of osteogenic differentiation in nature [21,61-63]. 


\section{Mechanosensitive miRNAs and Osteoblast Proliferation}

Not only did osteoblast differentiation change, but osteoblast proliferation also altered with the transformation of mechanical stimuli (Table 4). Experimental evidence showed that osteoblasts under compressive force at $294 \mathrm{~Pa}$ had slower cell growth and higher expression of miR-494-3p compared with no-compressive group cells. Moreover, overexpression of miR-494-3p repressed osteoblast proliferation assay through targeting Fgfr2 (fibroblast growth factor receptor 2) and Rock1 (Rho associated coiled-coil containing protein kinase 1) [36]. Zhang's group paid massive attention to the effects of mechanical unloading on osteoblast activity, and they found that a mechanical unloading of sensitive miRNA, miR-103 [64,65], was involved in osteoblast proliferation. Increasing miR-103 expression and a decreasing number of EdU (5-Ethynyl-2'-deoxyuridine) positive cells induced by mechanical unloading demonstrated that miR-103 was negatively correlated to MC3T3-E1 cell proliferation. The miR-103' target Cav1.2 (calcium voltage-gated channel), an L-type voltage-sensitive calcium channel (LTCC), decreased under the mechanical unloading environment, which was moderated by the miR-103 inhibitor [64,65]. Taken together, the roles of mechanosensitive miRNAs in bone cells were concentrated on osteogenic differentiation and osteoblast proliferation.

Table 4. Mechanosensitive miRNAs inhibit osteoblast proliferation.

\begin{tabular}{cccccc}
\hline miRNAs & Mechanical Stimuli & Methods & Target Gene & Samples & Reference \\
\hline miR-494-3p & Compressive force & $\begin{array}{c}294 \mathrm{~Pa}\left(2.0-4.0 \mathrm{~g} / \mathrm{cm}^{2}\right), \\
24 \mathrm{~h}\end{array}$ & Fgfr2, Rock1 & MC3T3-E1 & [36] \\
\hline miR-103 & Unloading & $24 \mathrm{rpm}, 48 \mathrm{~h}$ & Cav1.2 & MC3T3-E1 & {$[64,65]$} \\
\hline $\begin{array}{l}\text { Cav1.2: calcium voltage-gated channel; Fgfr2: fibroblast growth factor receptor 2; miR: microRNA; Rock1: Rho } \\
\text { associated coiled-coil containing protein kinase 1; rpm: revolutions per minute. }\end{array}$
\end{tabular}

\section{Mechanosensitive miRNAs and Bone Formation}

It is reported that some mechanosensitive miRNAs are involved in bone formation in vivo (Table 5). Accumulating evidence suggests that almost $40 \%$ of reports of exercise-sensitive miRNAs were in relation to skeletal muscle [66], but less to bone in vivo. Exercise, a natural method to investigate the influence of mechanical loading on bone formation in vivo, is well known to strongly benefit trabecular bone parameters, bone mineral density (BMD) and bone mechanical strength, including treadmill walking, swimming and artificial cyclic strain (four-point bending on tibia) [67-69]. Daily bouts of exercise [70] or high-frequency motions [71] were seen as the primary interventions to reduce the risk of bone loss. Conditional knockout (cKO) miR17-92 cluster in collagen type I-producing osteoblasts resulted in a 13-34\% reduction of total body bone mineral content, a $10 \%$ reduction in maximum load, a $28 \%$ reduction in the periosteal bone formation rate, but no change in bone toughness and the resorbing surface [72]. Interestingly, miR17-92 cluster cKO mice subjected to two weeks of mechanical exercise by four-point bending, revealed no obvious change in tibia periosteal bone formation, compared to wild-type mice [72]. Besides, Sengul reported that miR-92 inhibitor (antagomir-92) increased tibia TV (Tissue volume), BV/TV (Bone volume/tissue volume) and density by $7-16 \%$ after two weeks mechanical exercise, but a similar increase in the above parameters $(6-15 \%)$ was seen in the antagomir-NC (inhibitor negative control) treated group with two weeks mechanical exercise [73]. Both studies revealed that the mechanosensitive miR17-92 cluster blocked bone formation in response to mechanical exercise loading. miR-222, a potential regulator of an articular cartilage mechanotransduction pathway, increased in the anterior weight-bearing area of articular cartilage as compared with the posterior non-weight-bearing area with minimum contact pressure [74].

Apart from weight-bearing bone formation, alveolar bone formation was also influenced by mechanosensitive miRNAs under mechanical loading. As a matter of fact, alveolar bone formation and incisor tooth mechanical properties also decreased in miR17-92 cluster cKO mice [75]. The role of mechanosensitive miR-21 in PDLSCs has been investigated in vitro [51]. Similarly, miR-21 was 
dose- and time-responsive to orthodontic force, which induced alveolar bone formation in vivo [76]. During orthodontic tooth movement (OTM), miR-21 deficiency prevented force-induced alveolar bone formation just in the tensile side, while blocking bone resorption in both the compressive and tensile sides in miR-21 knockout mice [76]. Meanwhile, Liu, et al. indicated that miR-503-5p was involved in OTM and the overexpression of miR-503-5p reduced Runx2, Alp mRNA and protein expression, and decreased osteoblast numbers and osteoblastic bone formation in the OTM tension sides [22].

While a lack of mechanical loading or physical activity disturbed the delicate balance of the homeostasis of weight-bearing bones [77], and a reduction in bone formation is frequently observed in the aging and in paraplegics [78]. It was known that sense and response to mechanical stimuli in middle-aged and old mice was less than in young adults, which led to the aged skeleton diminishing in bone formation $[14,79,80]$. There is growing evidence that age-altered miRNAs modulated bone formation [81-83]. More recently, miR-188 was identified as a key regulator of the age-associated switch between osteoblast and adipocyte differentiation of BMSCs [84]. Notably, the miR-188 level was positively correlated with age in both mouse and human BMSCs, whereas it was negatively correlated with trabecular bone formation parameters (BV/TV, Tb.N (Trabecular number)) and tibia maximum mechanical load. With aging, miR-188 knockdown in animals reduced decrease rates of bone formation and tibia mechanical strength; conversely, miR-188 overexpression in transgenic mice revealed a substantial age-related reduction of bone formation and tibia maximum mechanical load. From the molecular mechanism point of view, miR-188 inhibited the osteogenic differentiation of BMSCs by targeting hystone deacetylase 9 (Hdac9). In addition, the miR-188 inhibitor-via a BMSC-specific aptamer-relieved age-induced osteoporosis and reduced femur maximum mechanical load [84]. It is reported that miR-214 [85] was up-regulated, while miR-142-5p [86], miR-31 [83], the miR 17-92 cluster [82], miR-let-7f, miR-125b, miR-199-3p and miR-222 [87] were down-regulated with age increasing in different osteogenic cells or bone tissue in vivo.

In addition, external mechanical unloading resulted in the deterioration of bone micro-structure, particularly the trabecular bone compartment and weak mechanical properties in vivo [88,89]. Although the mechanosensitive miR-103 family has been identified as negatively regulating osteoblast differentiation [23] and proliferation [64,65] in vitro, there is still conflicting evidence showing either stimulatory or inhibitory effects of the miR-103 family on bone formation under mechanical unloading in vivo [23,90]. Pretreatment with miR-103a inhibitor partly counteracted the decrease of bone formation caused by hind-limb unloading [23], nevertheless the expression of miR-103-3p (same with miR-30b-5p and miR-142-3p) was significantly declined in the serum of rhesus monkeys after long-duration bed-rest and positively correlated with BMD [90]. Bed-rest was a reliable model for the simulation of mechanical unloading and miRNAs, as putative circulating biomarkers of diseases, were stable in plasma and serum. Li's group also demonstrated the circulating miRNA profile of plasma from 16 individuals after 45 days of $-6^{\circ}$ head-down tilt bed-rest. 11 miRNAs including miR-103, -130 a, $-1234,-1290,-151-5 p,-151-3 p,-148 a,-199 a-3 p,-20 a,-363$, and -451a revealed dramatically decreased after 45 days of bed-rest, while the expressions of these miRNAs were recovered after 10 days of mechanical recovery, except miR-148a, -199a-3p and -151-3p. Additionally, several miRNAs, especially miR-1234, were identified in positive correlation with bone formation parameters [91]. Expressions of miR-214 [85], miR-139-3p, miR-339-3p, miR-132-3p, miR-487b, miR-2985 and miR-34b [60] have been demonstrated to alter in the bones of hind-limb unloading animals. Significantly, miR-214 level was reported to vary with natural age in human osteoporotic bone specimens and increase in $\mathrm{Alp}^{+}$cells isolated from bones after 28 days hind-limb unloading, which implied that miR-214 might be potentially sensitive to mechanical unloading and played a crucial role in bone formation [85]. Furthermore, miR-214 has been shown to repress osteogenic differentiation or bone formation in different osteogenic cells through binding to various protein coding genes, such as Osterix in C2C12 myoblast cells [92], activating transcription factor 4 (ATF4) in osteoblasts [85], and FGF in BMSCs [93]. The roles of mechanosensitive miRNAs in bone formation were showed in Table 5. 
Table 5. The roles of mechanosensitive miRNAs in bone formation.

\begin{tabular}{|c|c|c|c|c|}
\hline miRNAs & Mechanical Methods & Source & Supporting Observations & Reference \\
\hline miR17-92 cluster & $\begin{array}{l}\text { four-point bending device at } 2 \mathrm{~Hz} \text { for } \\
36 \text { cycles for } 2 \text { weeks }\end{array}$ & Osteoblast cKO mice & $\begin{array}{l}\text { Block tibia periosteal bone formation response to mechanical } \\
\text { exercise loading in the cKO mice; alveolar bone size and incisor } \\
\text { tooth mechanical properties decreased in the cKO mice. }\end{array}$ & {$[72,73,75]$} \\
\hline $\operatorname{miR}-222$ & $\begin{array}{l}\text { anterior weight-bearing and posterior } \\
\text { non-weight-bearing regions }\end{array}$ & bovine articular cartilage & $\begin{array}{c}\text { A potential regulator of an articular cartilage mechanotransduction } \\
\text { pathway. }\end{array}$ & [74] \\
\hline $\mathrm{miR}-21$ & $\begin{array}{l}\text { orthodontic force in periodontal } \\
\text { tissue at } 30 \mathrm{~g} \text { of force for } 7 \mathrm{~d}\end{array}$ & miR-21-/- mice & $\begin{array}{l}\text { miR-21 deficiency prevented force-induced alveolar bone } \\
\text { formation just in the tensile side, while blocking bone resorption in } \\
\text { both the compressive and tensile sides. }\end{array}$ & [76] \\
\hline $\operatorname{miR}-503-5 p$ & $\begin{array}{l}\text { the left maxillary first molars were } \\
\text { mesially stretched at } 50 \mathrm{~g} \text { of force for } \\
1,3,7,14 \mathrm{~d} \text { respectively }\end{array}$ & alveolar bones & $\begin{array}{l}\text { Agomir-503-5p decreased Run } x 2 \text {, Alp mRNA and protein } \\
\text { expression, decreased osteoblast numbers and osteoblastic bone } \\
\text { formation in the orthodontic tooth movement (OTM) tension sides. }\end{array}$ & [22] \\
\hline miR-188 & $\begin{array}{c}\text { 3, 6, 12, 18-month mice } \\
85 \text { human females and } 85 \text { males at } \\
\text { different ages }\end{array}$ & BMSCs & $\begin{array}{l}\text { miR-188 level increased with age. Further, miR-188 deficiency } \\
\text { revealed substantially reduced decrease of age-associated rates of } \\
\text { bone formation and tibia maximum mechanical load; miR-188 } \\
\text { transgenic mice determined opposite results; miR-188 inhibitor via } \\
\text { a BMSC-specific aptamer relieved age-induced osteoporosis and } \\
\text { reduction of femur maximum mechanical load. }\end{array}$ & [84] \\
\hline $\operatorname{miR}-214$ & $\begin{array}{l}20 \text { human females and } 20 \text { males at } \\
\text { different ages }\end{array}$ & Bone specimens & $\begin{array}{l}\text { Expression of miR-214 increased with age and was negatively } \\
\text { correlated with the expressions of bone formation marker genes. }\end{array}$ & [85] \\
\hline miR-142-5p & $\begin{array}{l}\text { Mice at } 10 \text { weeks and } 18 \text { months of } \\
\text { age }\end{array}$ & Bone callus & $\begin{array}{l}\text { miR-142-5p level was lower in the callus of aged mice than the } \\
\text { young group, and Agomir-142-5p repaired the aged bone fractures. }\end{array}$ & [86] \\
\hline $\mathrm{miR}-31$ & Mice at 2, 8, 25 months of age & MSCs and bone tissue & $\begin{array}{c}\text { miR-31 level showed a consistent decreased trend with age } \\
\text { increasing in MSCs and bone. }\end{array}$ & [83] \\
\hline
\end{tabular}


Table 5. Cont.

\begin{tabular}{|c|c|c|c|c|}
\hline miRNAs & Mechanical Methods & Source & Functions & Reference \\
\hline miR17-92 cluster & Mice at 4 and 16 months of age & BMSCs and bone tissue & $\begin{array}{l}\text { miR-17 mimics could partially rescue the osteogenesis of old MSCs } \\
\text { both in vitro an in vivo }\end{array}$ & [82] \\
\hline $\begin{array}{l}\text { miR-let-7f, }-199-3 p \\
\quad-125 b,-222\end{array}$ & $\begin{array}{c}22 \text { healthy rhesus macaques } \\
\text { young }(<5 \text { years), middle }(8-10 \text { years }) \text {, } \\
\text { old }(>12 \text { years, } n=9)\end{array}$ & BMSCs & $\begin{array}{l}\text { Analysis of miRNA expression profiles and qPCR results revealed a } \\
\text { down-regulation of miR-let-7f, miR-125b, miR-222 and miR-199-3p } \\
\text { in old rBMSCs. }\end{array}$ & [87] \\
\hline $\begin{array}{l}\text { miR-103-3p, -30b-5p, } \\
-142-3 p\end{array}$ & $\begin{array}{l}\text { 10-degree head-down tilt position for } \\
\text { 42-day long-duration bedrest }\end{array}$ & serum of rhesus monkeys & $\begin{array}{l}\text { Expressions of the three miRNAs declined in the serum of rhesus } \\
\text { monkeys after bedrest and positively correlated with BMD. }\end{array}$ & [90] \\
\hline $\begin{array}{c}\text { miR-103, -130a, -1234, } \\
-1290,-151-5 p,-151-3 p \\
-199 a-3 p,-20 a,-148 a, \\
-363,-451 a\end{array}$ & $\begin{array}{l}16 \text { male volunteers after } 45 \text { days of } \\
-6^{\circ} \text { head-down tilt bedrest }\end{array}$ & plasma of individuals & $\begin{array}{l}\text { These miRNAs were dramatically decreased after } 45 \text { days of } \\
\text { bedrest, while the expressions of these miRNAs were recovered } \\
\text { after } 10 \text { days of recovery, except miR-148a, 199a-3p and 151-3p. } \\
\text { Additionally, several miRNAs especially miR-1234 was identified } \\
\text { in positive correlation with bone formation parameters. }\end{array}$ & [91] \\
\hline $\operatorname{miR}-214$ & Hind-limb unloading for 28 days & $\mathrm{Alp}^{+}$cells and bone tissue & $\begin{array}{l}\text { miR-214 level was up-regulated after 28-day hind-limb unloading, } \\
\text { and Antagomir-214 counteracts unloading induced bone loss. }\end{array}$ & [85] \\
\hline miR-103a & Hind-limb unloading for 28 days & bone tissue & Antagomir-103a partly resumed unloading-caused bone loss. & [23] \\
\hline $\begin{array}{l}\text { miR-139-3p, }-339-3 p \\
-132-3 p,-487 b,-2985 \\
-34 b\end{array}$ & Hind-limb unloading for 21 days & bone tissue & $\begin{array}{l}\text { the expression levels of miR-139-3p, }-339-3 p \text { and }-132-3 p \text { were } \\
\text { up-regulated, and the expression levels of miR- } 487 \mathrm{~b},-2985 \text { and }-34 b \\
\text { were down-regulated in rat bone after three weeks tail suspension. }\end{array}$ & {$[60]$} \\
\hline
\end{tabular}

Alp: alkaline phosphatase; Alp ${ }^{+}$: Alp positive; BMD: bone mineral density; BMSCs: bone marrow mesenchymal stem cells; cKO: conditional knockout; d: days; miR: microRNA;

MSCs: mesenchymal stem cells; OTM: Orthodontic tooth movement; Runx2: Runt related transcription factor 2. 


\section{Conclusions and Perspectives}

An increasing number of studies are showing that some miRNAs (e.g., miR 17-92 cluster, miR-103 family) have been identified in response to different mechanical stimuli and to act as crucial regulators in osteogenic differentiation and bone formation. However, controversial functions of mechanosensitive miRNAs existed in osteogenic differentiation under different mechanical stimuli: (1) Stretch stress and FSS showed the opposite effects of mechanosensitive miRNAs on osteogenic differentiation, for instance miR-21 and miR-33; (2) The expression of the mechanosensitive miR-132 family showed the same trend under opposite mechanical stimuli.

The future perspectives for the application of mechanosensitive miRNAs may include: (1) several mechanosensitive miRNAs mimics or inhibitors potentially served as therapeutic approaches for osteopenia due to a lack of mechanical loading; (2) the potential application of mechanosensitive miRNAs as biomarkers to assess the extent of osteopenia induced by the alteration of mechanical stimuli in patients' serum, plasma or exosomes; (3) exercise-sensitive miRNAs presumably accounted for bone-muscle interactions, owing to exercise changing many miRNAs expression in skeletal muscles; (4) mechano-sensitive miRNAs related to bone resorption is a compelling future research direction, since osteoclastogenesis and osteoclast activity altered with different mechanical stimuli [94-96]. Despite the functional roles of mechanosensitive miRNAs in osteogenic differentiation and bone formation being elucidated in the present review, the mechanisms of miRNA response to different mechanical stimuli during bone remodeling and clinical practice remain to be investigated in future.

Acknowledgments: This work was supported by funds from the Natural Science Foundation of China (No. 31570940), the Shenzhen Science and Technology Project (JCYJ20160229174320053), the Peak Experience Project of NPU.

Author Contributions: Zhihao Chen wrote the whole manuscript. Airong Qian and Ge Zhang made the outline of the manuscript. Zhihao Chen, Yan Zhang and Lei Chen searched for literatures cited in introduction and roles of mechanosensitive miRNAs in bone formation. Chao Liang made corrections for the manuscript. All of the authors proofread and approved the final manuscript.

Conflicts of Interest: The authors declare no conflict of interest.

$\begin{array}{ll}\text { Abbreviations } \\ \text { Acvr2b } & \text { Activin receptor type IIB } \\ \text { ADSCs } & \text { Adipose-derived mesenchymal stem cells } \\ \text { Ago2 } & \text { Argonaute 2 } \\ \text { AKT } & \text { Serine/threonine kinase } \\ \text { ALP } & \text { Alkaline phosphatase } \\ \text { Alp } & \text { Alp positive } \\ \text { ATF4 } & \text { Activating transcription factor 4 } \\ \text { BFR } & \text { Bone formation rate } \\ \text { BMD } & \text { Bone mineral density } \\ \text { BMMs } & \text { Bone marrow monocytes } \\ \text { BMPR1A } & \text { Bone morphogenetic protein receptor-1A } \\ \text { BMSCs } & \text { Bone marrow mesenchymal stem cells } \\ \text { BMP } & \text { Bone morphogenetic protein } \\ \text { Bsp } & \text { Bone sialoprotein } \\ \text { BV/TV } & \text { Bone volume/tissue volume } \\ \text { cKO } & \text { Conditional knockout } \\ \text { Col I } & \text { Collage I } \\ \text { Cav1.2 } & \text { Calcium voltage-gated channel } \\ \text { Creb1 } & \text { CAMP responsive element binding protein 1 } \\ \text { DGCR8 } & \text { Digeorge syndrome critical region gene 8 } \\ \text { Ep300 } & \text { E1A binding protein p300 } \\ \text { EdU } & \text { 5-Ethynyl-2'-deoxyuridine } \\ \end{array}$




\begin{tabular}{|c|c|}
\hline ESW & Extracorporeal shockwave \\
\hline FAK & Focal adhesion kinase \\
\hline FGF & Fibroblast growth factor \\
\hline Fgf2 & Fibroblast growth factor 2 \\
\hline Fgfr2 & Fibroblast growth factor receptor 2 \\
\hline FSS & Fluid shear stress \\
\hline Hmga2 & High mobility group AT-hook 2 \\
\hline Hdac4 & Hystone deacetylase 4 \\
\hline Hdac9 & Hystone deacetylase 9 \\
\hline LTCC & L-type voltage-sensitive calcium channel \\
\hline MAR & Mineral apposition rate \\
\hline mTOR & Mammalian target of rapamycin \\
\hline MSCs & Mesenchymal stem cells \\
\hline miRNAs & MicroRNA \\
\hline OCCM & Immortalized osteocalcin positive cementoblasts \\
\hline mRNAs & Messenger RNAs \\
\hline Ocn & Osteocalcin \\
\hline OTM & Orthodontic tooth movement \\
\hline PCP & Planar-cell-polarity \\
\hline PDLCs & Periodontal ligament cells \\
\hline PDLSCs & Periodontal ligament stem cells \\
\hline PI3K & Phosphatidylinositol-3 kinase \\
\hline P70S6K & Ribosomal protein S6 kinase \\
\hline pri-miRNA & Primary transcript \\
\hline pre-miRNA & Precursor miRNA \\
\hline Pten & Phosphatase and tensin homolog \\
\hline RISC & RNA-Induced Silencing Complex \\
\hline Rock1 & Rho associated coiled-coil containing protein kinase 1 \\
\hline rpm & Revolutions per minute \\
\hline RPM & Random positioning machine \\
\hline Runx2 & Runt related transcription factor 2 \\
\hline RWVB & Rotating Wall Vessel Bioreactor \\
\hline Smad4 & SMAD family member 4 \\
\hline Tb.N & Trabecular number \\
\hline TV & Tissue volume \\
\hline TGF- $\beta$ & Transforming growth factor- $\beta$ \\
\hline UTR & Untranslated region \\
\hline WNT3A & WNT family member $3 \mathrm{~A}$ \\
\hline WNT 11 & WNT family member 11 \\
\hline
\end{tabular}

\section{References}

1. Huiskes, R.; Ruimerman, R.; van Lenthe, G.H.; Janssen, J.D. Effects of mechanical forces on maintenance and adaptation of form in trabecular bone. Nature 2000, 405, 704-706. [CrossRef] [PubMed]

2. Biewener, A.A. Bone and its functions: The mechanical adaptations of bones. Science 1985, 227, 629-630. [CrossRef] [PubMed]

3. Arpornmaeklong, P.; Pripatnanont, P.; Kittidumkerng, W.; Mitarnun, W. Effects of autogenous growth factors on heterotopic bone formation of osteogenic cells in small animal model. J. Cranio-Maxillofac. Surg. 2012, 40, 332-340. [CrossRef] [PubMed]

4. Yang, F.; Yang, D.; Tu, J.; Zheng, Q.; Cai, L.; Wang, L. Strontium enhances osteogenic differentiation of mesenchymal stem cells and in vivo bone formation by activating Wnt/catenin signaling. Stem Cells 2011, 29, 981-991. [CrossRef] [PubMed] 
5. Xin, M.; Yang, Y.; Zhang, D.; Wang, J.; Chen, S.; Zhou, D. Attenuation of hind-limb suspension-induced bone loss by curcumin is associated with reduced oxidative stress and increased vitamin $\mathrm{D}$ receptor expression. Osteoporos. Int. 2015, 26, 2665-2676. [CrossRef] [PubMed]

6. Wang, H.; Wan, Y.; Tam, K.F.; Ling, S.; Bai, Y.; Deng, Y.; Liu, Y.; Zhang, H.; Cheung, W.H.; Qin, L.; et al. Resistive vibration exercise retards bone loss in weight-bearing skeletons during 60 days bed rest. Osteoporos. Int. 2012, 23, 2169-2178. [CrossRef] [PubMed]

7. Sibonga, J.D.; Spector, E.R.; Johnston, S.L.; Tarver, W.J. Evaluating bone loss in iss astronauts. Aerosp. Med. Hum. Perform. 2015, 86, A38-A44. [CrossRef] [PubMed]

8. Ng, A.H.; Omelon, S.; Variola, F.; Allo, B.; Willett, T.L.; Alman, B.A.; Grynpas, M.D. Adynamic bone decreases bone toughness during aging by affecting mineral and matrix. J. Bone Miner. Res. 2016, 31, 369-379. [CrossRef] [PubMed]

9. Maycas, M.; McAndrews, K.A.; Sato, A.Y.; Pellegrini, G.G.; Brown, D.M.; Allen, M.R.; Plotkin, L.I.; Gortazar, A.R.; Esbrit, P.; Bellido, T. Pthrp-derived peptides restore bone mass and strength in diabetic mice: Additive effect of mechanical loading. J. Bone Miner. Res. 2016, 32, 486-497. [CrossRef] [PubMed]

10. De Oliveira, M.L.; Bergamaschi, C.T.; Silva, O.L.; Nonaka, K.O.; Wang, C.C.; Carvalho, A.B.; Jorgetti, V.; Campos, R.R.; Lazaretti-Castro, M. Mechanical vibration preserves bone structure in rats treated with glucocorticoids. Bone 2010, 46, 1516-1521. [CrossRef] [PubMed]

11. Nam, J.; Perera, P.; Gordon, R.; Jeong, Y.H.; Blazek, A.D.; Kim, D.G.; Tee, B.C.; Sun, Z.; Eubank, T.D.; Zhao, Y.; et al. Follistatin-like 3 is a mediator of exercise-driven bone formation and strengthening. Bone 2015, 78, 62-70. [CrossRef] [PubMed]

12. Qian, A.R.; Hu, L.F.; Gao, X.; Zhang, W.; Di, S.M.; Tian, Z.C.; Yang, P.F.; Yin, D.C.; Weng, Y.Y.; Shang, P. Large gradient high magnetic field affects the association of MACF1 with actin and microtubule cytoskeleton. Bioelectromagnetics 2009, 30, 545-555. [CrossRef] [PubMed]

13. Lloyd, S.A.; Lewis, G.S.; Zhang, Y.; Paul, E.M.; Donahue, H.J. Connexin 43 deficiency attenuates loss of trabecular bone and prevents suppression of cortical bone formation during unloading. J. Bone Miner. Res. 2012, 27, 2359-2372. [CrossRef] [PubMed]

14. Holguin, N.; Brodt, M.D.; Silva, M.J. Activation of wnt signaling by mechanical loading is impaired in the bone of old mice. J. Bone Miner. Res. 2016, 31, 2215-2226. [CrossRef] [PubMed]

15. Galli, C.; Passeri, G.; Macaluso, G.M. Osteocytes and WNT: The mechanical control of bone formation. J. Dent. Res. 2010, 89, 331-343. [CrossRef] [PubMed]

16. Macfarlane, L.A.; Murphy, P.R. MicroRNA: Biogenesis, function and role in cancer. Curr. Genom. 2010, 11, 537-561. [CrossRef] [PubMed]

17. Ambros, V. The functions of animal microRNAs. Nature 2004, 431, 350-355. [CrossRef] [PubMed]

18. Brennecke, J.; Hipfner, D.R.; Stark, A.; Russell, R.B.; Cohen, S.M. Bantam encodes a developmentally regulated microRNA that controls cell proliferation and regulates the proapoptotic gene hid in drosophila. Cell 2003, 113, 25-36. [CrossRef]

19. Park, J.; Wada, S.; Ushida, T.; Akimoto, T. The microRNA-23a has limited roles in bone formation and homeostasis in vivo. Physiol. Res. 2015, 64, 711-719. [PubMed]

20. Chen, L.; Holmstrom, K.; Qiu, W.; Ditzel, N.; Shi, K.; Hokland, L.; Kassem, M. MicroRNA-34a inhibits osteoblast differentiation and in vivo bone formation of human stromal stem cells. Stem Cells 2014, 32, 902-912. [CrossRef] [PubMed]

21. Lian, J.B.; Stein, G.S.; van Wijnen, A.J.; Stein, J.L.; Hassan, M.Q.; Gaur, T.; Zhang, Y. MicroRNA control of bone formation and homeostasis. Nat. Rev. Endocrinol. 2012, 8, 212-227. [CrossRef] [PubMed]

22. Liu, L.; Liu, M.; Li, R.; Liu, H.; Du, L.; Chen, H.; Zhang, Y.; Zhang, S.; Liu, D. MicroRNA-503-5p inhibits stretch-induced osteogenic differentiation and bone formation. Cell Biol. Int. 2017, 41, 112-123. [CrossRef] [PubMed]

23. Zuo, B.; Zhu, J.; Li, J.; Wang, C.; Zhao, X.; Cai, G.; Li, Z.; Peng, J.; Wang, P.; Shen, C.; et al. MicroRNA-103a functions as a mechanosensitive microRNA to inhibit bone formation through targeting Runx2. J. Bone Miner. Res. 2015, 30, 330-345. [CrossRef] [PubMed]

24. Kloosterman, W.P.; Plasterk, R.H. The diverse functions of microRNAs in animal development and disease. Dev. Cell 2006, 11, 441-450. [CrossRef] [PubMed]

25. Friedman, R.C.; Farh, K.K.; Burge, C.B.; Bartel, D.P. Most mammalian mRNAs are conserved targets of microRNAs. Genome Res. 2009, 19, 92-105. [CrossRef] [PubMed] 
26. Ha, M.; Kim, V.N. Regulation of microRNA biogenesis. Nat. Rev. Mol. Cell Biol. 2014, 15, 509-524. [CrossRef] [PubMed]

27. Arfat, Y.; Xiao, W.Z.; Ahmad, M.; Zhao, F.; Li, D.J.; Sun, Y.L.; Hu, L.; Zhihao, C.; Zhang, G.; Iftikhar, S.; et al. Role of microRNAs in osteoblasts differentiation and bone disorders. Curr. Med. Chem. 2015, 22, 748-758. [CrossRef] [PubMed]

28. Gaur, T.; Hussain, S.; Mudhasani, R.; Parulkar, I.; Colby, J.L.; Frederick, D.; Kream, B.E.; van Wijnen, A.J.; Stein, J.L.; Stein, G.S.; et al. Dicer inactivation in osteoprogenitor cells compromises fetal survival and bone formation, while excision in differentiated osteoblasts increases bone mass in the adult mouse. Dev. Biol. 2010, 340, 10-21. [CrossRef] [PubMed]

29. Mizoguchi, F.; Izu, Y.; Hayata, T.; Hemmi, H.; Nakashima, K.; Nakamura, T.; Kato, S.; Miyasaka, N.; Ezura, Y.; Noda, M. Osteoclast-specific Dicer gene deficiency suppresses osteoclastic bone resorption. J. Cell. Biochem. 2010, 109, 866-875. [CrossRef] [PubMed]

30. Wang, K.C.; Garmire, L.X.; Young, A.; Nguyen, P.; Trinh, A.; Subramaniam, S.; Wang, N.; Shyy, J.Y.; Li, Y.S.; Chien, $\mathrm{S}$. Role of microRNA-23b in flow-regulation of $\mathrm{Rb}$ phosphorylation and endothelial cell growth. Proc. Natl. Acad. Sci. USA 2010, 107, 3234-3239. [CrossRef] [PubMed]

31. Qin, X.; Wang, X.; Wang, Y.; Tang, Z.; Cui, Q.; Xi, J.; Li, Y.S.; Chien, S.; Wang, N. MicroRNA-19a mediates the suppressive effect of laminar flow on cyclin D1 expression in human umbilical vein endothelial cells. Proc. Natl. Acad. Sci. USA 2010, 107, 3240-3244. [CrossRef] [PubMed]

32. Hua, W.; Zhang, M.; Wang, Y.; Yu, L.; Zhao, T.; Qiu, X.; Wang, L. Mechanical stretch regulates microRNA expression profile via NF-kB activation in C2C12 myoblasts. Mol. Med. Rep. 2016, 14, 5084-5092. [CrossRef] [PubMed]

33. Hu, B.; Song, J.T.; Qu, H.Y.; Bi, C.L.; Huang, X.Z.; Liu, X.X.; Zhang, M. Mechanical stretch suppresses microRNA-145 expression by activating extracellular signal-regulated kinase $1 / 2$ and upregulating angiotensin-converting enzyme to alter vascular smooth muscle cell phenotype. PLoS ONE 2014, 9, e96338. [CrossRef] [PubMed]

34. Rullman, E.; Mekjavic, I.B.; Fischer, H.; Eiken, O. Planhab (planetary habitat simulation): The combined and separate effects of 21 days bed rest and hypoxic confinement on human skeletal muscle miRNA expression. Physiol. Rep. 2016, 4, e12753. [CrossRef] [PubMed]

35. Rezen, T.; Kovanda, A.; Eiken, O.; Mekjavic, I.B.; Rogelj, B. Expression changes in human skeletal muscle miRNAs following 10 days of bed rest in young healthy males. Acta Physiol. 2014, 210, 655-666. [CrossRef] [PubMed]

36. Iwawaki, Y.; Mizusawa, N.; Iwata, T.; Higaki, N.; Goto, T.; Watanabe, M.; Tomotake, Y.; Ichikawa, T.; Yoshimoto, K. Mir-494-3p induced by compressive force inhibits cell proliferation in MC3T3-E1 cells. J. Biosci. Bioeng. 2015, 120, 456-462. [CrossRef] [PubMed]

37. Li, J.; Hu, C.; Han, L.; Liu, L.; Jing, W.; Tang, W.; Tian, W.; Long, J. miR-154-5p regulates osteogenic differentiation of adipose-derived mesenchymal stem cells under tensile stress through the WNT/PCP pathway by targeting Wnt11. Bone 2015, 78, 130-141. [CrossRef] [PubMed]

38. Guan, Y.J.; Yang, X.; Wei, L.; Chen, Q. Mir-365: A mechanosensitive microRNA stimulates chondrocyte differentiation through targeting histone deacetylase 4. FASEB J. 2011, 25, 4457-4466. [CrossRef] [PubMed]

39. Qi, L.; Zhang, Y. The microRNA 132 regulates fluid shear stress-induced differentiation in periodontal ligament cells through mtor signaling pathway. Cell. Physiol. Biochem. 2014, 33, 433-445. [CrossRef] [PubMed]

40. Wang, H.; Sun, Z.; Wang, Y.; Hu, Z.; Zhou, H.; Zhang, L.; Hong, B.; Zhang, S.; Cao, X. miR-33-5p, a novel mechano-sensitive microRNA promotes osteoblast differentiation by targeting Hmga2. Sci. Rep. 2016, 6, 23170. [CrossRef] [PubMed]

41. Guo, Y.; Wang, Y.; Liu, Y.; Liu, Y.; Zeng, Q.; Zhao, Y.; Zhang, X.; Zhang, X. MicroRNA-218, microRNA-191*, microRNA-3070a and microRNA-33 are responsive to mechanical strain exerted on osteoblastic cells. Mol. Med. Rep. 2015, 12, 3033-3038. [CrossRef] [PubMed]

42. Wang, Y.; Zou, X.; Guo, Y.; Wang, L.; Liu, Y.; Zeng, Q.; Zhang, X. Mechanical strain affects some microRNA profiles in pre-oeteoblasts. Cell. Mol. Biol. Lett. 2015, 20, 586-596. [CrossRef] [PubMed]

43. Wang, L.; Hu, H.; Cheng, Y.; Chen, J.; Bao, C.; Zou, S.; Wu, G. Screening the expression changes in microRNAs and their target genes in mature cementoblasts stimulated with cyclic tensile stress. Int. J. Mol. Sci. 2016, 17, 2024. [CrossRef] [PubMed] 
44. Chen, J.H.; Liu, C.; You, L.; Simmons, C.A. Boning up on wolff's law: Mechanical regulation of the cells that make and maintain bone. J. Biomech. 2010, 43, 108-118. [CrossRef] [PubMed]

45. Zhang, C.; Li, J.; Zhang, L.; Zhou, Y.; Hou, W.; Quan, H.; Li, X.; Chen, Y.; Yu, H. Effects of mechanical vibration on proliferation and osteogenic differentiation of human periodontal ligament stem cells. Arch. Oral Biol. 2012, 57, 1395-1407. [CrossRef] [PubMed]

46. Wei, F.L.; Wang, J.H.; Ding, G.; Yang, S.Y.; Li, Y.; Hu, Y.J.; Wang, S.L. Mechanical force-induced specific microRNA expression in human periodontal ligament stem cells. Cells Tissues Organs 2014, 199, 353-363. [CrossRef] [PubMed]

47. Chang, M.; Lin, H.; Luo, M.; Wang, J.; Han, G. Integrated miRNA and mRNA expression profiling of tension force-induced bone formation in periodontal ligament cells. In Vitro Cell. Dev. Biol. Anim. 2015, 51, 797-807. [CrossRef] [PubMed]

48. Mai, Z.H.; Peng, Z.L.; Zhang, J.L.; Chen, L.; Liang, H.Y.; Cai, B.; Ai, H. miRNA expression profile during fluid shear stress-induced osteogenic differentiation in mc3t3-e1 cells. Chin. Med. J. 2013, 126, 1544-1550. [PubMed]

49. Hu, L.F.; Li, J.B.; Qian, A.R.; Wang, F.; Shang, P. Mineralization initiation of MC3T3-E1 preosteoblast is suppressed under simulated microgravity condition. Cell Biol. Int. 2015, 39, 364-372. [CrossRef] [PubMed]

50. Chen, Z.; Zhao, F.; Qi, Y.; Hu, L.; Li, D.; Yin, C.; Su, P.; Zhang, Y.; Ma, J.; Qian, J.; et al. Simulated microgravity alters the expression of cytoskeleton- and ATP-binding-related genes in MLO-Y4 osteocytes. Acta Astronaut. 2016, 129, 186-192. [CrossRef]

51. Wei, F.; Liu, D.; Feng, C.; Zhang, F.; Yang, S.; Hu, Y.; Ding, G.; Wang, S. MicroRNA-21 mediates stretch-induced osteogenic differentiation in human periodontal ligament stem cells. Stem Cells Dev. 2015, 24, 312-319. [CrossRef] [PubMed]

52. Li, H.; Yang, F.; Wang, Z.; Fu, Q.; Liang, A. MicroRNA-21 promotes osteogenic differentiation by targeting small mothers against decapentaplegic 7. Mol. Med. Rep. 2015, 12, 1561-1567. [PubMed]

53. Li, C.; Li, C.; Yue, J.; Huang, X.; Chen, M.; Gao, J.; Wu, B. miR-21 and miR-101 regulate PLAP-1 expression in periodontal ligament cells. Mol. Med. Rep. 2012, 5, 1340-1346. [PubMed]

54. Chang, M.; Lin, H.; Fu, H.; Wang, B.; Han, G.; Fan, M. MicroRNA-195-5p regulates osteogenic differentiation of periodontal ligament cells under mechanical loading. J. Cell Physiol. 2017. [CrossRef] [PubMed]

55. Chen, Y.; Mohammed, A.; Oubaidin, M.; Evans, C.A.; Zhou, X.; Luan, X.; Diekwisch, T.G.; Atsawasuwan, P. Cyclic stretch and compression forces alter microRNA-29 expression of human periodontal ligament cells. Gene 2015, 566, 13-17. [CrossRef] [PubMed]

56. Hofmann, A.; Ritz, U.; Hessmann, M.H.; Alini, M.; Rommens, P.M.; Rompe, J.D. Extracorporeal shock wave-mediated changes in proliferation, differentiation, and gene expression of human osteoblasts. J. Trauma 2008, 65, 1402-1410. [CrossRef] [PubMed]

57. Hu, J.; Liao, H.; Ma, Z.; Chen, H.; Huang, Z.; Zhang, Y.; Yu, M.; Chen, Y.; Xu, J. Focal adhesion kinase signaling mediated the enhancement of osteogenesis of human mesenchymal stem cells induced by extracorporeal shockwave. Sci. Rep. 2016, 6, 20875. [CrossRef] [PubMed]

58. Yan, J.; Zhang, C.; Zhao, Y.; Cao, C.; Wu, K.; Zhao, L.; Zhang, Y. Non-viral oligonucleotide antimiR-138 delivery to mesenchymal stem cell sheets and the effect on osteogenesis. Biomaterials 2014, 35, 7734-7749. [CrossRef] [PubMed]

59. Eskildsen, T.; Taipaleenmaki, H.; Stenvang, J.; Abdallah, B.M.; Ditzel, N.; Nossent, A.Y.; Bak, M.; Kauppinen, S.; Kassem, M. MicroRNA-138 regulates osteogenic differentiation of human stromal (mesenchymal) stem cells in vivo. Proc. Natl. Acad. Sci. USA 2011, 108, 6139-6144. [CrossRef] [PubMed]

60. Hu, Z.; Wang, Y.; Sun, Z.; Wang, H.; Zhou, H.; Zhang, L.; Zhang, S.; Cao, X. miRNA-132-3p inhibits osteoblast differentiation by targeting Ep300 in simulated microgravity. Sci. Rep. 2015, 5, 18655. [CrossRef] [PubMed]

61. Sera, S.R.; Zur Nieden, N.I. MicroRNA regulation of skeletal development. Curr. Osteoporos. Rep. 2017. [CrossRef] [PubMed]

62. Luan, X.; Zhou, X.; Trombetta-eSilva, J.; Francis, M.; Gaharwar, A.K.; Atsawasuwan, P.; Diekwisch, T.G.H. MicroRNAs and periodontal homeostasis. J. Dent. Res. 2017, 96, 491-500. [CrossRef] [PubMed]

63. Gennari, L.; Bianciardi, S.; Merlotti, D. MicroRNAs in bone diseases. Osteoporos. Int. 2017, 28, 1191-1213. [CrossRef] [PubMed] 
64. Sun, Z.; Cao, X.; Zhang, Z.; Hu, Z.; Zhang, L.; Wang, H.; Zhou, H.; Li, D.; Zhang, S.; Xie, M. Simulated microgravity inhibits L-type calcium channel currents partially by the up-regulation of mir-103 in MC3T3-E1 osteoblasts. Sci. Rep. 2015, 5, 8077. [CrossRef] [PubMed]

65. Sun, Z.; Cao, X.; Hu, Z.; Zhang, L.; Wang, H.; Zhou, H.; Li, D.; Zhang, S.; Xie, M. miR-103 inhibits osteoblast proliferation mainly through suppressing Cav1.2 expression in simulated microgravity. Bone 2015, 76, 121-128. [CrossRef] [PubMed]

66. Kirby, T.J.; McCarthy, J.J. MicroRNAs in skeletal muscle biology and exercise adaptation. Free Radic. Biol. Med. 2013, 64, 95-105. [CrossRef] [PubMed]

67. Sun, X.; Li, F.; Ma, X.; Ma, J.; Zhao, B.; Zhang, Y.; Li, Y.; Lv, J.; Meng, X. The effects of combined treatment with naringin and treadmill exercise on osteoporosis in ovariectomized rats. Sci. Rep. 2015, 5, 13009. [CrossRef] [PubMed]

68. Ju, Y.I.; Sone, T.; Ohnaru, K.; Tanaka, K.; Fukunaga, M. Effect of swimming exercise on three-dimensional trabecular bone microarchitecture in ovariectomized rats. J. Appl. Physiol. (1985) 2015, 119, 990-997. [CrossRef] [PubMed]

69. Kesavan, C.; Mohan, S.; Oberholtzer, S.; Wergedal, J.E.; Baylink, D.J. Mechanical loading-induced gene expression and bmd changes are different in two inbred mouse strains. J. Appl. Physiol. (1985) 2005, 99, 1951-1957. [CrossRef] [PubMed]

70. Nogueira, R.C.; Weeks, B.K.; Beck, B.R. An in-school exercise intervention to enhance bone and reduce fat in girls: The capo kids trial. Bone 2014, 68, 92-99. [CrossRef] [PubMed]

71. Ozcivici, E.; Garman, R.; Judex, S. High-frequency oscillatory motions enhance the simulated mechanical properties of non-weight bearing trabecular bone. J. Biomech. 2007, 40, 3404-3411. [CrossRef] [PubMed]

72. Mohan, S.; Wergedal, J.E.; Das, S.; Kesavan, C. Conditional disruption of miR17-92 cluster in collagen type i-producing osteoblasts results in reduced periosteal bone formation and bone anabolic response to exercise. Physiol. Genom. 2015, 47, 33-43. [CrossRef] [PubMed]

73. Sengul, A.; Santisuk, R.; Xing, W.; Kesavan, C. Systemic administration of an antagomir designed to inhibit miR-92, a regulator of angiogenesis, failed to modulate skeletal anabolic response to mechanical loading. Physiol. Res. 2013, 62, 221-226. [PubMed]

74. Dunn, W.; DuRaine, G.; Reddi, A.H. Profiling microRNA expression in bovine articular cartilage and implications for mechanotransduction. Arthritis Rheumatol. 2009, 60, 2333-2339. [CrossRef] [PubMed]

75. Ibrahim, M.; Mohan, S.; Xing, M.J.; Kesavan, C. Conditional knockout of the microRNA 17-92 cluster in type-I collagen-expressing cells decreases alveolar bone size and incisor tooth mechanical properties. Folia Biol. (Praha) 2016, 62, 175-179. [PubMed]

76. Chen, N.; Sui, B.D.; Hu, C.H.; Cao, J.; Zheng, C.X.; Hou, R.; Yang, Z.K.; Zhao, P.; Chen, Q.; Yang, Q.J.; et al. MicroRNA-21 contributes to orthodontic tooth movement. J. Dent. Res. 2016, 95, 1425-1433. [CrossRef] [PubMed]

77. Aguirre, J.I.; Plotkin, L.I.; Stewart, S.A.; Weinstein, R.S.; Parfitt, A.M.; Manolagas, S.C.; Bellido, T. Osteocyte apoptosis is induced by weightlessness in mice and precedes osteoclast recruitment and bone loss. J. Bone Miner. Res. 2006, 21, 605-615. [CrossRef] [PubMed]

78. Zhang, P.; Hamamura, K.; Yokota, H. A brief review of bone adaptation to unloading. Genom. Proteom. Bioinform. 2008, 6, 4-7. [CrossRef]

79. Mirzaali, M.J.; Schwiedrzik, J.J.; Thaiwichai, S.; Best, J.P.; Michler, J.; Zysset, P.K.; Wolfram, U. Mechanical properties of cortical bone and their relationships with age, gender, composition and microindentation properties in the elderly. Bone 2016, 93, 196-211. [CrossRef] [PubMed]

80. Raghavan, M.; Sahar, N.D.; Kohn, D.H.; Morris, M.D. Age-specific profiles of tissue-level composition and mechanical properties in murine cortical bone. Bone 2012, 50, 942-953. [CrossRef] [PubMed]

81. Candini, O.; Spano, C.; Murgia, A.; Grisendi, G.; Veronesi, E.; Piccinno, M.S.; Ferracin, M.; Negrini, M.; Giacobbi, F.; Bambi, F.; et al. Mesenchymal progenitors aging highlights a miR-196 switch targeting hoxb7 as master regulator of proliferation and osteogenesis. Stem Cells 2015, 33, 939-950. [CrossRef] [PubMed]

82. Liu, W.; Qi, M.; Konermann, A.; Zhang, L.; Jin, F.; Jin, Y. The p53/miR-17/smurf1 pathway mediates skeletal deformities in an age-related model via inhibiting the function of mesenchymal stem cells. Aging (Albany NY) 2015, 7, 205-218. [CrossRef] [PubMed] 
83. He, X.; Zhang, W.; Liao, L.; Fu, X.; Yu, Q.; Jin, Y. Identification and characterization of microRNAs by high through-put sequencing in mesenchymal stem cells and bone tissue from mice of age-related osteoporosis. PLoS ONE 2013, 8, e71895. [CrossRef] [PubMed]

84. Li, C.J.; Cheng, P.; Liang, M.K.; Chen, Y.S.; Lu, Q.; Wang, J.Y.; Xia, Z.Y.; Zhou, H.D.; Cao, X.; Xie, H.; et al. MicroRNA-188 regulates age-related switch between osteoblast and adipocyte differentiation. J. Clin. Investig. 2015, 125, 1509-1522. [CrossRef] [PubMed]

85. Wang, X.; Guo, B.; Li, Q.; Peng, J.; Yang, Z.; Wang, A.; Li, D.; Hou, Z.; Lv, K.; Kan, G.; et al. miR-214 targets ATF4 to inhibit bone formation. Nat. Med. 2013, 19, 93-100. [CrossRef] [PubMed]

86. Tu, M.; Tang, J.; He, H.; Cheng, P.; Chen, C. miR-142-5p promotes bone repair by maintaining osteoblast activity. J. Bone Miner. Metab. 2016, 35, 255-264. [CrossRef] [PubMed]

87. Yu, J.M.; Wu, X.; Gimble, J.M.; Guan, X.; Freitas, M.A.; Bunnell, B.A. Age-related changes in mesenchymal stem cells derived from rhesus macaque bone marrow. Aging Cell 2011, 10, 66-79. [CrossRef] [PubMed]

88. Zhao, F.; Li, D.; Arfat, Y.; Chen, Z.; Liu, Z.; Lin, Y.; Ding, C.; Sun, Y.; Hu, L.; Shang, P.; et al. Reloading partly recovers bone mineral density and mechanical properties in hind limb unloaded rats. Acta Astronaut. 2014, 105, 57-65. [CrossRef]

89. Lloyd, S.A.; Loiselle, A.E.; Zhang, Y.; Donahue, H.J. Connexin 43 deficiency desensitizes bone to the effects of mechanical unloading through modulation of both arms of bone remodeling. Bone 2013, 57, 76-83. [CrossRef] [PubMed]

90. Chen, J.; Li, K.; Pang, Q.; Yang, C.; Zhang, H.; Wu, F.; Cao, H.; Liu, H.; Wan, Y.; Xia, W.; et al. Identification of suitable reference gene and biomarkers of serum miRNAs for osteoporosis. Sci. Rep. 2016, 6, 36347. [CrossRef] [PubMed]

91. Ling, S.; Zhong, G.; Sun, W.; Liang, F.; Wu, F.; Li, H.; Li, Y.; Zhao, D.; Song, J.; Jin, X.; et al. Circulating microRNAs correlated with bone loss induced by 45 days of bed rest. Front. Physiol. 2017, 8, 69. [CrossRef] [PubMed]

92. Shi, K.; Lu, J.; Zhao, Y.; Wang, L.; Li, J.; Qi, B.; Li, H.; Ma, C. MicroRNA-214 suppresses osteogenic differentiation of $\mathrm{C} 2 \mathrm{C} 12$ myoblast cells by targeting osterix. Bone 2013, 55, 487-494. [CrossRef] [PubMed]

93. Guo, Y.; Li, L.; Gao, J.; Chen, X.; Sang, Q. miR-214 suppresses the osteogenic differentiation of bone marrow-derived mesenchymal stem cells and these effects are mediated through the inhibition of the jnk and p38 pathways. Int. J. Mol. Med. 2017, 39, 71-80. [CrossRef] [PubMed]

94. Mehta, M.; Strube, P.; Peters, A.; Perka, C.; Hutmacher, D.; Fratzl, P.; Duda, G.N. Influences of age and mechanical stability on volume, microstructure, and mineralization of the fracture callus during bone healing: Is osteoclast activity the key to age-related impaired healing? Bone 2010, 47, 219-228. [CrossRef] [PubMed]

95. Nozaki, K.; Kaku, M.; Yamashita, Y.; Yamauchi, M.; Miura, H. Effect of cyclic mechanical loading on osteoclast recruitment in periodontal tissue. J. Periodontal Res. 2010, 45, 8-15. [CrossRef] [PubMed]

96. Kurata, K.; Uemura, T.; Nemoto, A.; Tateishi, T.; Murakami, T.; Higaki, H.; Miura, H.; Iwamoto, Y. Mechanical strain effect on bone-resorbing activity and messenger RNA expressions of marker enzymes in isolated osteoclast culture. J. Bone Miner. Res. 2001, 16, 722-730. [CrossRef] [PubMed]

(C) 2017 by the authors. Licensee MDPI, Basel, Switzerland. This article is an open access article distributed under the terms and conditions of the Creative Commons Attribution (CC BY) license (http://creativecommons.org/licenses/by/4.0/). 